Education, Psychology, and Sociology.

\title{
Masalah Vape di Sekolah Dalam Kalangan Awal Remaja
}

Mohd Razimi Husin ${ }^{1}$, George Chong ${ }^{1}$, Abdul Rahman Hamid ${ }^{1}$, Baida Azahar ${ }^{1}$, Muaz Muzaffa $^{1}$, Farah Diana Ahmad Kemchi ${ }^{1}$, Nur Ezzaty Mandzoor Ahmed ${ }^{1}$, Zulkarnain Zaharudin ${ }^{1}$, Mohamad Amirul Ismail', Ahmad Naqib Md Norazni @ Md Yasin ${ }^{1}$, Mohamad Alif Azizan ${ }^{1}$

\author{
${ }^{1}$ Faculty of Human Development, Universitas Pendidikan Sultan Idris. Tanjong \\ Malim, Malaysia.
}

Article History

Received:

11.02 .2020

Revised:

11.03.2020

Accepted:

11.04 .2020

*Corresponding Author:

Mohd Razimi bin Husin

Email:

razimi@fpm.upsi.edu.my

This is an open access article, licensed under: $\mathrm{CC}-\mathrm{BY}-\mathrm{SA}$

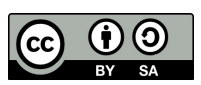

Abstrak: Masalah tingkah laku vape dalam kalangan awal remaja iaitu remaja yang berumur 12 tahun ke bawah dan 12 tahun keatas adalah satu perkara yang membimbangkan di dalam kalangan pelajar sekolah di Malaysia. Objektif kajian ini iaitu untuk menghuraikan punca berlakunya masalah vape, mengenal pasti strategi, pendekatan atau cadangan untuk mengurangkan masalah vape di sekolah, mengenal pasti keberkesanan sesi kaunseling terhadap pelajar yang terlibat dalam gejala vape, mengenal pasti kesan vape ke atas pelajar peringkat awal remaja, dan untuk mengkaji tahap perkembangan masalah vape di sekolah. Kaedah kajian ini meliputi reka bentuk kajian, instrument kajian dan prosedur atau proses menganalisis data bagi menjawab persoalan-persoalan kajian yang telah dikemukakan lebih awal. Dapatan kajian yang boleh disimpulkan menurut Ustaz Tengku perkembangan vape disekolah adalah semakin meningkat dan ia sukar dikawal. Hal ini demikian kerana wujudnya vape yang sukar untuk dikenal. Fenomena penggunaan vape menjadi ikutan anak muda dan kanak-kanak. Hal ini amat membimbangkan kerana ia bertentangan dengan Pelan Strategik Kebangsaan Bagi Kawalan Tembakau 2015-2020 dengan misi menjadikan Malaysia negara bebas daripada sebarang bentuk amalan merokok menjelang 2045.

Kata Kunci: Awal Remaja, Sekolah, Vape.

\section{Vape Problems in School among Early Teens}

Abstract: Vape behavior problems among early adolescents who are 12 and under 12 are a concern among Malaysian schoolchildren. The objectives of this study were to identify the causes of vape problems, identify strategies, approaches or recommendations for reducing vape problems in schools, identify the effectiveness of counseling sessions for students involved in vape symptoms, identify vape effects on early adolescent students, and to study the developmental stages of vape problems in schools. The research methods include study design, instrumentation and data analysis procedures or processes to answer the research questions that were presented earlier. The findings of the study that can be concluded according to Ustaz Tengku the development of vape school are increasing and it is difficult to control. This is because of the vape that is difficult to identify. The phenomenon of the use of vape has been traced to young people and children. This is alarming as it goes against the National Strategic Plan for Tobacco Control 2015-2020 with the mission of making Malaysia a country free from any form of smoking by 2045.

Keywords: Early Teens, School, Vape. 


\section{Pendahuluan}

Pendidikan di Malaysia adalah suatu usaha berterusan ke arah memperkembangkan lagi potensi individu secara menyeluruh dan bersepadu untuk mewujudkan insan yang seimbang dan harmonis dari segi intelek, rohani, emosi, dan jasmani berdasarkan kepercayaan dan kepatuhan kepada Tuhan. Akan tetapi, masalah tingkah laku vape dalam kalangan awal remaja iaitu remaja yang berumur 12 tahun ke bawah dan 12 tahun keatas adalah satu perkara yang membimbangkan di dalam kalangan pelajar sekolah di Malaysia.

Vape atau rokok elektrik adalah salah satu jenis dari penghantar nikotin elektronik. Rokok jenis ini dirancang untuk membantu pecandu rokok tembakau mulai berhenti merokok. Dengan beralih dari rokok tembakau ke rokok elektrik, secara perlahan mereka belajar untuk berhenti merokok. Selain itu juga, cecair di dalam tabung ini mengandung nikotin, gliserin, serta penambah rasa, seperti rasa buahbuahan. Beberapa rokok elektrik memiliki bateri dan cartridge yang dapat diisi secara berulang-ulang. Seterusnya, gliserin berfungsi untuk menghasilkan wap air. Penelitian menunjukkan bahawa menghisap gliserin dapat menyebabkan iritasi saluran pernafasan pada beberapa individu. Seterusnya, perisa seperti rasa coklat, vanila, buah-buahan, dan lainnya menyebabkan penghisap ketagih dengan vape tersebut.

Selanjutnya, rokok vape pada dasarnya memiliki banyak jenis, berbagai bentuk dan ukuran. Contohnya, bentuk pen, portable, jam tangan, dan sebagainya. Kesannya, seseorang guru di sekolah akan sukar mengenalpasti vape yang dibawa oleh remaja kerana ia mempunyai bentuk yang unik. Oleh itu, seseorang guru perlulah membuat sedikit kajian tentang vape atau rokok elektrik tentang bentuk-entuk yang terkini yang dijual di pasaran. Aneka bentuk dan ukuran vape disajikan pada Rajah 1.
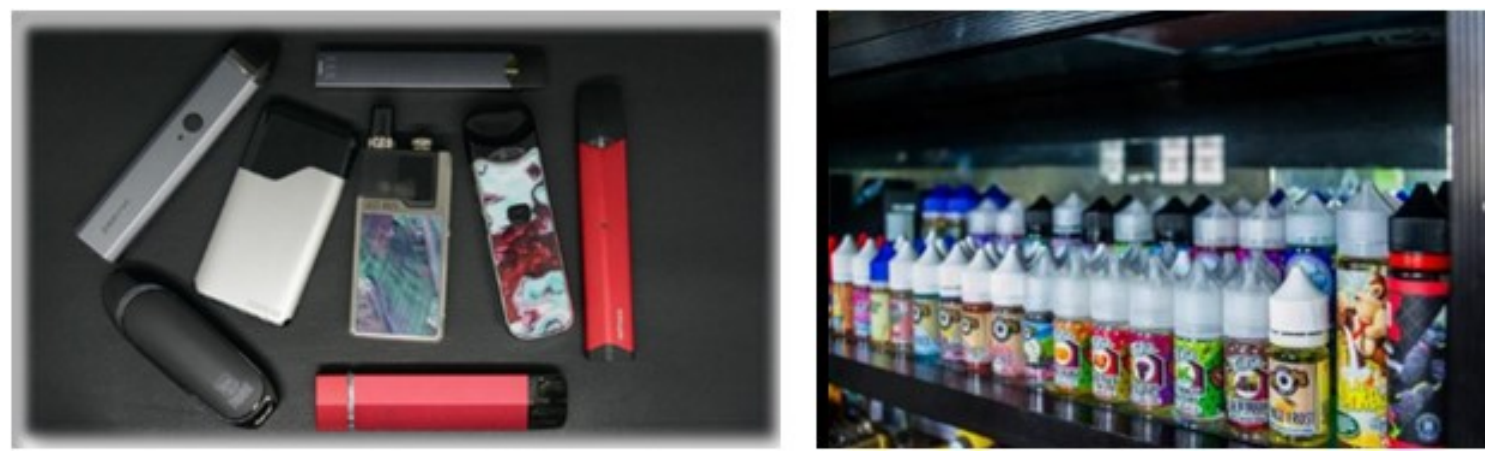

Rajah 1. Jenis-Jenis Vape

Secara umum, bagian-bagian vape disajikan pada Rajah 2.

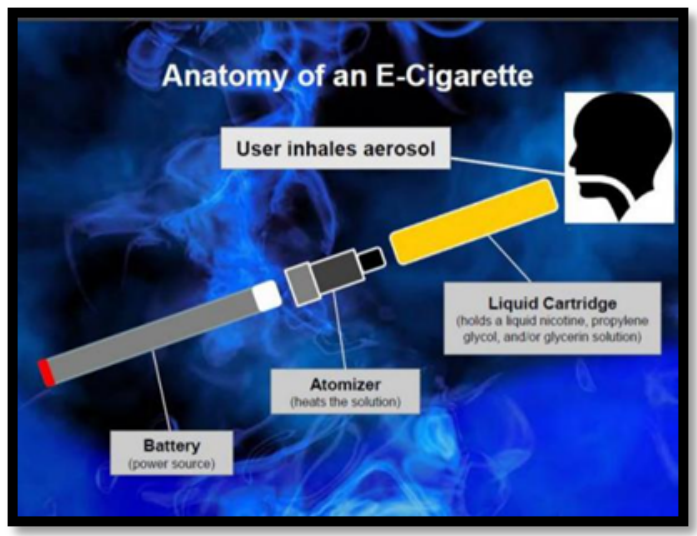

Rajah 2. Bagian-Bagian Vape 
Mohd Razimi Husin, George Chong, Abdul Rahman Hamid, Baida Azahar, Muaz Muzaffa, Farah Diana Ahmad Kemchi, Nur Ezzaty Mandzoor Ahmed, Zulkarnain Zaharudin, Mohamad Amirul Ismail, Ahmad Naqib Md Norazni @ Md Yasin, Mohamad Alif Azizan.

Masalah Vape di Sekolah Dalam Kalangan Awal Remaja.

Journal of Humanities and Social Sciences, vol. 2, no. 1, pp. 34-46, April 2020. DOI: 10.36079/lamintang.jhass-0201.101

Objektif-Objektif kajian ini meliputi:

1. Menghuraikan punca berlakunya masalah vape dalam kalangan disiplin pelajar sekolah rendah.

2. Mengenal pasti strategi, pendekatan atau cadangan untuk mengurangkan masalah vape di sekolah.

3. Mengenal pasti keberkesanan sesi kaunseling terhadap pelajar yang terlibat dalam gejala vape.

4. Mengenal pasti kesan vape ke atas pelajar peringkat awal remaja.

5. Untuk mengkaji tahap perkembangan masalah vape di sekolah.

\section{Sorotan Kajian}

Rogers [1] menyatakan bahawa adolescence bermaksud membesar menjadi matang. Remaja dikatakan berusia di antara 11 hingga 21 tahun merupakan transisi antara zaman kanak-kanak dengan zaman dewasa yang melibatkan perubahan biologi, psikologi, social, dan ekonomi serta melibatkan perubahan peringkat tidak matang ke peringkat matang [2]. Zaman remaja bermula dari akil baligh dan berakhir apabila memasuki alam dewasa. Ia merupakan satu tempoh peralihan dalam pusingan hidup yang melibatkan banyak perubahan yang berlaku. Zaman remaja dikatakan satu proses untuk memperolehi sikap dan kepercayaan bagi penglibatan yang berkesan dalam masyarakat.

Kajian bandingan di antara penggunaan rokok elektronik, NRT dan placebo menunjukkan tiada perbezaan signifikan di dalam kejayaan untuk berhenti merokok [3]. Tambahan pula, mereka yang menggunakan rokok elektronik menunjukkan kesukaran mereka untuk menghentikan tabiat merokok akibat kebergantungan kepada nikotin [4]. Kajian oleh Public Health England (PHE) yang menyatakan rokok elektronik adalah $95 \%$ lebih selamat berbanding rokok tembakau telah dikritik hebat kerana ianya 5 berdasarkan beberapa kajian dan mempunyai pelbagai kelemahan serta penglibatan penajaan oleh syarikat tembakau. Tambahan pula, majoriti pengguna rokok elektronik yang masih merokok (dual users) dikhuatiri tidak akan mengurangkan risiko kematian. Risiko jangka panjang rokok elektronik masih tidak diketahui dan langkah pengawalan serta pemantauan adalah perlu apabila ianya tidak diharamkan.

Rokok Elektronik (Electronic Nicotine Delivery Systems atau E-Cigarette) adalah sebuah inovasi dari bentuk rokok konvensional (rokok biasa) menjadi rokok moden. Pada masa sekarang, rokok elektronik juga dikenali sebagai vape atau vapour $[5,6]$. Vape atau rokok elektronik (e-rokok) terdiri daripada bateri, alat pemanas, alat penakung cecair dan corong untuk menghisap. Apabila pengguna menghisap e-rokok ini, alat pemanas akan diaktifkan, dan menyebabkan cecair di dalam penakung ini mengalami proses pengewapan tanpa sebarang proses pembakaran [7]. Etter dan Bullen [8] mendapati bahawa rokok elektronik adalah produk tembakau yang paling popular dalam kalangan pelajar menengah pertengahan (3.9\%) dan menengah atasan (13.4\%) di Amerika Syarikat. Di antara tahuntahun 2011 dan 2014, penggunaan rokok elektronik telah meningkat secara signifikan sebaliknya penggunaan produk tembakau lain seperti rokok, curut dan sebagainya menurun.

Menurut Bahtiar dan Rahardja [9], vape mengandung bahan-bahan yang lebih selamat dibandingkan dengan rokok tembakau, vape dipromosikan lebih selamat untuk kesihatan. Selain itu rokok elektronik juga menghasilkan wap air bukan asap sehingga dibenarkan untuk lingkungan sekitar. Sebagai alternatif pengganti rokok tembakau, vape dapat digunakan sebagai media bagi para perokok aktif untuk perlahan-lahan berhenti merokok. Rokok elektrik hampir sama dengan rokok tembakau sehingga perokok dapat sedikit mengurangkan keinginan merokok menggunakan vape. Dipercayai bahawa vape dapat menggantikan kebiasaan merokok yang tidak sihat dan berbahaya. Oleh itu, vape boleh dikatakan lebih baik dari rokok, ramai yang menganggap minimal mengurangi risiko bahaya dari merokok, kerana cecair vape tidak mengandung tar dan juga setelah menghisap vape dapat menghilangkan hasrat untuk merokok malah merokok jadi tidak sedap hingga akhirnya berhenti merokok.

Menurut Tjiptono [10] pada tahap harga tertentu jika manfaat dirasakan pengguna meningkat, nilai akan meningkat juga, dan sebaliknya pada tahap harga nilai tertentu atau perkhidmatan akan meningkat dengan peningkatan faedah dirasakan. Persepsi harga dari sudut pandangan pengguna sering digunakan sebagai penunjuk nilai jika harga sepadan jika dikaitkan dengan faedah yang dirasakan melalui item atau perkhidmatan. Maka dapat disimpulkan bahawa pada tingkat harga tertentu, jika manfaat yang dirasakan meningkat, maka persepsi pengguna terutamanya pengguna di peringkat awal remaja akan meningkat. Jika persepsi nilai yang dilihat oleh pelanggan lebih tinggi, ia akan mewujudkan keinginan pelanggan untuk membuat pembelian vape. 
Mohd Razimi Husin, George Chong, Abdul Rahman Hamid, Baida Azahar, Muaz Muzaffa, Farah Diana Ahmad Kemchi, Nur Ezzaty Mandzoor Ahmed, Zulkarnain Zaharudin, Mohamad Amirul Ismail, Ahmad Naqib Md Norazni @ Md Yasin, Mohamad Alif Azizan.

Masalah Vape di Sekolah Dalam Kalangan Awal Remaja.

Journal of Humanities and Social Sciences, vol. 2, no. 1, pp. 34-46, April 2020. DOI: 10.36079/lamintang.jhass-0201.101

Perilaku merokok dilihat dari berbagai sudut pandang sangat merugikan, baik untuk diri sendiri maupun orang di sekelilingnya. Tingkah laku merokok dilihat dari pelbagai perspektif sangat merugikan, baik untuk diri sendiri dan orang-orang di sekelilingnya. Dilihat dari sisi individu yang berkenaan, terdapat beberapa penyelidikan yang menyokong kenyataan itu. Dari segi kesihatan, pengaruh bahan kimia rokok seperti nikotin, $\mathrm{CO}$ (karbon monoksida) dan tar akan mendorong kerja dari sistem saraf pusat dan sistem saraf simpatik, yang mengakibatkan tekanan darah meningkat dan kadar jantung meningkat, merangsang kanser dan pelbagai penyakit seperti penyempitan arteri, tekanan darah tinggi, jantung, paru-paru, dan bronkitis kronik [11]

Di Malaysia, pengguna rokok elektronik adalah dari pelbagai latar belakang. Consumers Association of Penang melaporkan bahawa aduan yang mereka terima dari para guru bahawa kanakkanak berumur 12 tahun sudah mula menggunakan rokok elektronik. Belum ditemui kajian menyeluruh mengenai profil vape di Malaysia. Namun, menurut Gravely [12], kesedaran mengenai rokok elektronik di Malaysia berada di tahap sederhana (62\%) berbanding Netherlands (2013: 88\%), Korea (2010: 79\%), Amerika Syarikat (2010: 73\%), Australia (2013: 66\%), United Kingdom (2010: 54\%), Canada (2010: 40\%), dan China (2009: 31\%). Kesedaran mengenai rokok elektronik disajikkan pada Jadual 1.

Jadual 1. Kesedaran Mengenai Rokok Elektronik

\begin{tabular}{ccc}
\hline TAHUN & NEGARA & PERATUS (\%) \\
\hline 2009 & China & 31 \\
\hline 2010 & Canada & 40 \\
\hline 2010 & Korea & 79 \\
\hline 2010 & Amerika Syarikat & 73 \\
\hline 2010 & United Kingdom & 54 \\
\hline 2013 & Australia & 66 \\
\hline 2013 & Netherlands & 88 \\
\hline 2013 & Malaysia & 62 \\
\hline
\end{tabular}

\section{Metodologi Kajian}

Menurut Hornby [13], metadologi merupakan satu set kaedah yang digunakan untuk menjalankan kajian kea atas subjek kajian yang tertentu. Oleh itu, bahagian ini akan membincangkan reka bentuk kajian, instrument kajian dan prosedur atau proses menganalisis data bagi menjawab persoalanpersoalan kajian yang telah dikemukakan lebih awal. Metadologi menerangkan cara sesuatu masalah yang dikaji dan sebab sesuatu kaedah dan teknik tertentu digunakan. Tujuan metadologi adalah untuk membantu memahami dengna lebih luas lagi tentang pengaplikasian kaedah dengan membuat huraian tentang proses kajian. Pengkaji telah memilih utuk menemu ramah seorang guru dari Sekolah Rendah Agama Al Mutaqqin Wangsa Melawati, Kuala Lumpur pada tarikh 22 Oktober 2019.

\subsection{Reka Bentuk Kajian}

Reka bentuk kajian merupakan satu tatacara pengolahan data yang dipungut berdasarkan perancangan khusus dan sistematik terhadap konsep pembentukan rangkaian hubungan antara pemboleh ubah yang terlibat dalam sesuatu kajian. Kajian yang dilakukan adalah dalam bentuk kajian tinjauan.

\subsection{Pengumpulan Data}

Bagi pengumpulan data, kajian ini menggunakan dua kaedah dalam pengumpulan data iaitu data primer dan data sekunder. Data primer adalah merujuk kepada data yang dikumpulkan sendiri oleh penyelidik iaitu melalui temubual dengan guru. Manakala pengumpulan data sekunder pula adalah lebih mengutamakan penyelidikan perpustakaan dan data tersebut telah dikumpul daripada kajiankajian berkaitan yang dilakukan sebelum ini oleh penyelidik lain sama ada dalam bentuk artikel, artikel jurnal, tesis, buku, majalah, kertas seminar dan sebagainya. Kajian-kajian yang berkaitan dijadikan sebagai rujukan bagi mengupas dengan lebih lanjut tentang kajian yang dilakukan dengan kajian yang lain dan ianya dikupaskan di kajian lepas ataupun sorotan kajian. 
Mohd Razimi Husin, George Chong, Abdul Rahman Hamid, Baida Azahar, Muaz Muzaffa, Farah Diana Ahmad Kemchi, Nur Ezzaty Mandzoor Ahmed, Zulkarnain Zaharudin, Mohamad Amirul Ismail, Ahmad Naqib Md Norazni @ Md Yasin, Mohamad Alif Azizan.

Masalah Vape di Sekolah Dalam Kalangan Awal Remaja.

Journal of Humanities and Social Sciences, vol. 2, no. 1, pp. 34-46, April 2020. DOI: 10.36079/lamintang.jhass-0201.101

\subsection{Instrumen Kajian}

Instrumen ialah alat untuk mengumpul data yang dikehendaki bagi menjawab soalan penyelidikan yang telah ditetapkan. Maka, instrumentasi ialah proses menyediakan alat mengumpul data. Instrumen kajian diperlukan untuk mendalami konsep berkaitan sikap, persepsi, keterangan latar belakang dan segala sumber yang berbentuk primer atau sekunder. Dalam kajian ini instrument yang digunakan untuk mendapatkan data adalah menggunakan kaedah kualitatif iaitu temubual dan kaedah rujukan. Kajian kualitatif adalah kajian yang tidak dapat dijelaskan dengan data numerika, yang mana terdapat perkara-perkara tertentu yang memerlukan pemerhatian yang teliti terutamanya yang berunsur emosi, motivasi, dan empati.

\subsection{Temubual Semi Struktur}

Dalam kaedah temubual, pengkaji telah menggunakan keadah temubual semi struktur iaitu pengkaji telah mengajukan beberapa soalan kepada responden. Temubual semi struktur bersifat felksibel di mana responden dapat menghuraikan apa yang difikirkannya kepada penyelidik. Pengkaji telah menemu bual seorang guru yang bernama En. Tengku Muhd Khaidir dari Sekolah Rendah Agama AL Mutaqqin, Wangsa Melawati. Pengkaji telah menyediakan beberapa soalan yang berkaitan dengan masalah vape di sekolah dalam kalangan awal remaja. Demi mendapatkan data dan maklumat ini, pengkaji telah memilih En. Tengku Muhd Khaidir kerana beliau mempunyai pengalaman dalam mengendalikan kes disiplin pelajar berkaitan dengan masalah vape. Berdasarkan objektif yang telah disenaraikan pengkaji telah mengeluarkan 2 soalan bagi setiap objektif bagi mendapatkan data dan maklumat. Soalan pada temubual bentangkan pada Jadual 2.

\section{Jadual 2. Soalan pada Temubual}

\begin{tabular}{ll}
\hline \multicolumn{1}{c}{ SOALAN } \\
\hline 1. & \multicolumn{1}{c}{ Apakah pendapat cikgu mengenai gejala vape pada zaman sekarang? } \\
\hline 2. & $\begin{array}{l}\text { Apakah punca berlakunya masalah vape dalam kalangan pelajar di } \\
\text { sekolah? }\end{array}$ \\
\hline 3. & $\begin{array}{l}\text { Pendekatan manakah yang lebih berkesan dalam mencegah masalah } \\
\text { vape dalam kalangan pelajar kempen/ individu? }\end{array}$ \\
\hline 4. & $\begin{array}{l}\text { Apakah strategi yang boleh dilakukan oleh ibu bapa dalam } \\
\text { mengatasi masalah vape dalam kalangan pelajar? }\end{array}$ \\
\hline 5. & Bagaimanakah guru di sini mengambil alih dan menasihat pelajar \\
yang bermasalah?
\end{tabular}

\subsection{Rujukan Perpustakaan}

Selain itu, bagi melengkapkan kajian, pengkaji telah mencari dan membaca pelbagai sumber seperti buku, kamus, blog dan internet bagi mendapatkan maklumat yang berkaitan. Rujukan ini sedikit sebanyak membantu pengkaji dalam mendapatkan maklumat tentang kajian yang pengkaji lakukan. Rujukan yang dilakukan adalah seperti artikel, artikel jurnal, tesis, buku, majalah dan sebagainya. Hal ini untuk memberikan maklumat tentang kajian yang dilakukan penyelidik lain bagi membuat perbandingan dengan kajian lepas. 
Mohd Razimi Husin, George Chong, Abdul Rahman Hamid, Baida Azahar, Muaz Muzaffa, Farah Diana Ahmad Kemchi, Nur Ezzaty Mandzoor Ahmed, Zulkarnain Zaharudin, Mohamad Amirul Ismail, Ahmad Naqib Md Norazni@ Md Yasin, Mohamad Alif Azizan.

Masalah Vape di Sekolah Dalam Kalangan Awal Remaja.

Journal of Humanities and Social Sciences, vol. 2, no. 1, pp. 34-46, April 2020. DOI: 10.36079/lamintang.jhass-0201.101

\section{Dapatan Kajian}

\subsection{Punca Masalah Vape Dalam Kalangan Awal Remaja di Sekolah}

Antara punca yang menyebabkan berlakunya masalah vape dalam kalangan pelajar awal remaja di sekolah ialah perasaan ingin mencuba sesuatu yang baru. Didapati punca utama remaja terlibat dalam masalah vape adalah disebabkan keinginan untuk mencuba sesuatu yang baru yang tidak pernah mereka lakukan. Aspek ini mempunyai peratusan yang agak tinggi berbanding aspek-aspek lain. Pada usia remaja, mereka mengalami perubahan dari segi peningkatan usia, pemikiran dan keadaan sekeliling. Ketika melalui proses-proses perkembangan pada keadaan sekeliling, akan wujud perkaraperkara yang tidak pernah mereka lihat atau alami seperti vape. Oleh itu, remaja akan mempunyai keinginan untuk mencuba menghisap vape yang tidak pernah mereka alami. Kajian lepas yang dilakukan oleh Asmak [14] mengenai salah laku sosial remaja masa kini menunjukkan faktor ingin mencuba juga tinggi iaitu sebanyak $48 \%$.

Seterusnya, dapatan kajian juga menunjukkan bahawa pengaruh rakan juga turut mendorong remaja melakukan aktiviti-aktiviti yang tidak sihat termasuklah menghisap vape. Berdasarkan maklumat yang telah diperoleh, remaja mudah menerima ajakan dari rakan-rakan kerana mereka percaya apa yang dilakukan oleh rakan mereka adalah betul dan boleh mendatangkan keseronokan. Hal ini demikian kerana, remaja lebih banyak meluangkan masa bersama rakan berbanding dengan ibu bapa mereka. Oleh itu, remaja yang kurang motivasi diri akan lebih mudah terpengaruh dengan gelaja yang tidak sihat ini terutamanya adalah menghisap vape diluar pengetahuan ibu bapa mereka. Semakin kuat keinginan remaja untuk mencari keseronokan, semakin rendahlah kawalan dalaman diri mereka.

Selain pengaruh rakan, media sosial menjadi elemen penting yang menarik perhatian remaja untuk mencuba sesuatu termasuk rokok dan vape. Penerimaan sosial sangat penting pada mereka menyebabkan ada yang sanggup mengambil risiko serta menerima cabaran agar dilihat mengikut peredaran zaman.Tidak dinafikan pengaruh televisyen dan media sosial menyebabkan remaja ini ada perspektif sebegini kerana kalau dilihat filem atau drama terutama luar negara memaparkan pelakon wanita seksi dengan rokok di jari. Malah, terdapat juga artis sendiri yang memperkenalkan vape di media sosial. Imej itu kelihatan menarik pada remaja membuatkan mereka menjejak langkah tersebut.

Antara punca lainnya ialah ibu bapa remaja. Dalam kajian ini didapati ibu bapa jarang berada di rumah dan sering sibuk dengan kerja. Keadaan ini akan menyebabkan anak-anak bosan untuk berada di rumah. Mereka akan lebih gemar untuk bersama dengan rakan-rakan mereka bagi mengisi kekosongan. Keberangkalian untuk mereka melakukan perkara-perkara yang tidak elok seperti menghisap vape boleh wujud kerana kurangnya pengawasan dari ibu bapa. Ibu bapa yang sibuk dengan kerja boleh menyebabkan hubungan antara anak dengan ibu bapa renggang. Apabila anakanak pulang dari sekolah, ibu bapa tiada di rumah. Apabila ibu bapa jarang berada di rumah, keadaan ini akan menyebabkan kurangnya komunikasi antara ibu bapa dengan anak-anak mereka tentang keperluan dan masalah yang dihadapi oleh anak-anak mereka. Oleh itu, hubungan interaksi yang lemah antara ibu bapa dan anak akan menyebabkan remaja hilang tempat mengadu dan mudah terjebak dengan gejala yang tidak sihat dengan menghisap vape. Dapatan kajian di sokong oleh kajian Barnes dan Olson [15] yang mendapati komunikasi yang baik antara ibu bapa dan remaja akan menyebabkan hubungan keluarga semakin rapat, wujud kasih sayang dan proses penyelesaian masalah akan berlaku dengan mudah. Punca masalah vape di kalangan awal remaja di sekolah dibentangkan pada Jadual 3.

Jadual 3. Punca Masalah Vape di Kalangan Awal Remaja di Sekolah

\begin{tabular}{c}
\hline Perasaan ingin mencuba sesuatu yang baru \\
\hline Pengaruh rakan \\
\hline Pengaruh media sosial \\
\hline Kurang perhatian ibu bapa \\
\hline
\end{tabular}

\subsection{Pendekatan, Strategi atau Cadangan untuk Mencegah Masalah Vape Dalam Kalangan Pelajar}


Mohd Razimi Husin, George Chong, Abdul Rahman Hamid, Baida Azahar, Muaz Muzaffa, Farah Diana Ahmad Kemchi, Nur Ezzaty Mandzoor Ahmed, Zulkarnain Zaharudin, Mohamad Amirul Ismail, Ahmad Naqib Md Norazni @ Md Yasin, Mohamad Alif Azizan.

Masalah Vape di Sekolah Dalam Kalangan Awal Remaja.

Journal of Humanities and Social Sciences, vol. 2, no. 1, pp. 34-46, April 2020. DOI: 10.36079/lamintang.jhass-0201.101

\subsubsection{Peranan Ibu Bapa}

Hasil daripada temubual yang dijalankan terdapat beberapa strategi yang boleh dilakukan oleh ibu bapa bagi mencegah masalah vape dalam kalangan remaja. Antaranya ialah ibu bapa seharusnya tidak menunjukkan kelakukan negatif dihadapan anak-anak. Pada peringkat awal remaja, perkembangan emosi para pelajar ini mula untuk beroperasi dimana mereka akan menilai tingkah laku yang dilakukan oleh ibu bapa meraka. Ibu bapa merupakan role model kepada anak-anak segala perbuatan yang dilakukan oleh ibu bapa sama ada positif atau negatif akan menjadi ikutan kepada anak-anak. Pelajar menganggap perbuatan yang dilakukan oleh ibu bapa mereka adalah baik dan boleh dicontohi.

Hal ini dikatakan demikian kerana pada peringkat awal remaja, remaja akan menjadikan persekitaran mereka sebagai contoh dalam melakukan sesuatu perkara. Sekiranya ibu bapa mereka menghisap vape di rumah secara terbuka di hadapan para pelajar ini berkemungkinan besar mereka akan terpengaruh dan mempunyai rasa ingin mencuba. Para pelajar ini akan cuba mencuba menghisap vape kepunyaan ibu bapa mereka secara sembunyi-sembunyi tanpa pengetahuan ibu bapa mereka. Oleh itu, ibu bapa perlulah memastikan sekiranya mereka ingin menghisap vape ianya perlulah dilakukan diluar perhatian anak-anak serta memastikan vape tersebut diletakkan di tempat tersembunyi atau tempat yang tidak dapat dicapai oleh anak-anak.

"Ibu bapa sepatutnya bagi saya kena pantau tingkah laku anak-anak. Sebagai contoh, pelajar kecil tiada masalah tahun 1, 2 dan 3 dia memang tiada masalah tetapi untuk pelajar 4, 5 dan 6 dia dah ada satu sifat yang ingin mencuba sangat-sangat dalam diri dia dan dari situ ibu bapa perlu memberi peranan dalam memantu pergerakkan anak-anak".

Selain itu, hasil daripada temubual yang dijalankan mendapati bahawa ibu bapa perlulah memantau tingkah laku anak-anak mereka. Ibu bapa perlulah memainkan peranan dalam memantau anak-anak supaya mereka tidak terlibat dalam gejala menghisap vape. Pemantauan perlulah diberikan kepada para pelajar yang berusia 10 tahun dan keatas di mana pada masa ini remaja mula membentuk personaliti sendiri dimana para pelajar sudah mula melalui proses baligh. Para pelajar ini tidak kira lelaki atau perempuan akan cenderung untuk membentuk sebuah personaliti hasil daripada pengamatan mereka terhadap persekitaran sekeliling. Pada waktu ini mula menunjukkan tingkah laku yang sesuai dengan jantina mereka di mana mereka mula menilai sesuatu yang dilakukan oleh orang yang lebih dewasa seperti ibu bapa dan guru, mula bergaul dengan rakan-rakan dan mempunyai rasa ingin tahu yang mendalam.

Pemantuan oleh ibu bapa adalah amat penting bagi memastikan para pelajar ini tidak terlibat dalam gejala menghisap vape. Ibu bapa perlulah memantau setiap tingkah laku anak-anak dari segi dengan siapa mereka bergaul, minat mereka, media sosial yang mereka gunakan dan lain lain lagi. Hal ini dikatakan demikian kerana berkemungkinan besar para pelajar akan terjebak dengan gejala menghisap vape disebabkan oleh ajakkan oleh rakan-rakan mereka. Kekuatan rasa ingin tahu yang berlebihan serta ajakkan oleh rakan-rakan menyebabkan para pelajar terjebak dengan gejala menghisap vape. Pemantauan terhadap media sosial yang digunakan anak-anak juga perlu diberi perhatian oleh ibu bapa. Hal ini kerana kemajuan arus teknologi masa kini menyebabkan pelbagai maklumat dapat diakses dengan mudah dihujung jari. Pemantuan perlulah dilakukan oleh ibu bapa seperti jenis media sosial yang digunakan oleh anak-anak, apa yang diikuti dan lain-lain lagi. Pemantauan yang efektif akan menyebabkan para pelajar tidak terikut dan terjebak kea rah perkara yang tidak mendatangkan faedah ini. Contoh kes masalah vape dibentangkan pada Rajah 3.

Isu vape di kalangan pelajar perlulah diberi perhatian kerana ianya semakin membimbangkan apabila terdapat segelintir pelajar sekolah rendah juga kini telah dilapor berjinak-jinak dalam menghisap vape secara terbuka. Disebabkan oleh perkembangan teknologi yang semakin meluas kini, peranti eletronik ini semakin mudah untuk didapati di mana-mana sahaja oleh itu ibu bapa perlulah memainkan peranan mereka dalam meastikan gejala vape ini dapat ditangani dengan sebaiknya. Ibu bapa perlulah menceritakan tentang keburukkan vape ini kepada anak-anak mereka bagi memastikan mereka tidak terjebak dalam aktiviti menghisap vape. Vape mendatangkan banyak keburukkan seperti masalah kesihatan kepada penggunanya. Ibu bapa boleh menunjukkan tentang kesan-kesan yang akan berlaku sekiranya para pelajar menghisap vape. Hal ini akan membuatkan mereka berasa takut dan menjauhi diri mereka dari vape. Oleh itu, didikan daripada awal lagi perlulah diberikan kepada anakanak bagi memastikan mereka paham dan mengerti tentang bahayanya pengunaan vape terhadap diri 
Mohd Razimi Husin, George Chong, Abdul Rahman Hamid, Baida Azahar, Muaz Muzaffa, Farah Diana Ahmad Kemchi, Nur Ezzaty Mandzoor Ahmed, Zulkarnain Zaharudin, Mohamad Amirul Ismail, Ahmad Naqib Md Norazni @ Md Yasin, Mohamad Alif Azizan.

Masalah Vape di Sekolah Dalam Kalangan Awal Remaja.

Journal of Humanities and Social Sciences, vol. 2, no. 1, pp. 34-46, April 2020. DOI: 10.36079/lamintang.jhass-0201.101

mereka. Ibu bapa juga perlu menegur anak-anak mereka sekiranya mereka mula memberikan minat terhadap vape.

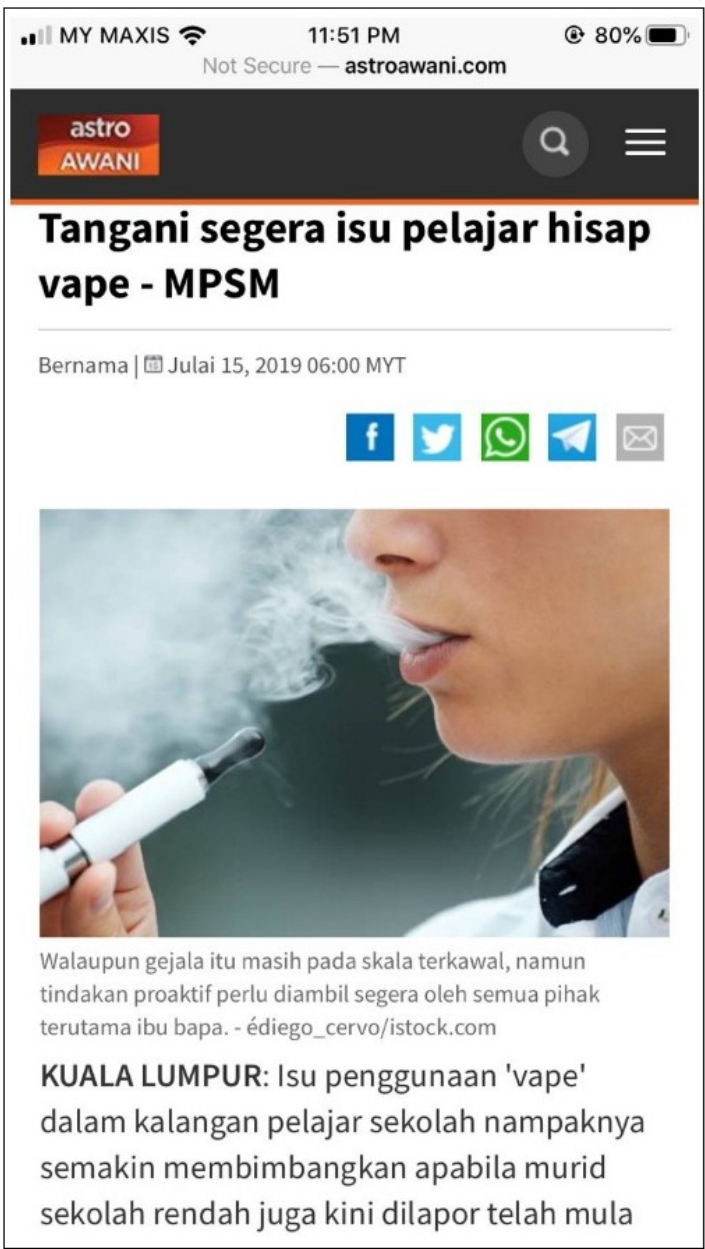

Rajah 3. Kes Masalah Vape

\subsubsection{Pendekatan Secara Individu atau Kumpulan}

Melalui temubual pengkaji dengan En. Tengku Muhd Khindir semasa di Sekolah Rendah Agama Al Mutaqqin, Wangsa Melawati. Pengkaji mendapati bahawa pendekatan individu terhadap pelajar adalah cara yang terbaik dan berkesan dalam mencegah vape dan rokok. Seperti yang dinyatakan, apabila ditujukan soalan tentang pendapat individu En. Tengku Muhd Khaidir,.

"kaunseling secara individu lagi berkesan berbanding dengan kempen atau secara berkumpulan ini”.

Ini adalah kerana semasa kaunseling dibuat secara individu, para guru boleh mengenali anak muridnya secara individu. Melalui ini, mereka akan mengenali sesama diri dengan lebih dekat dan memahami apa masalah yang dilalui oleh pelajar tersebut. Oleh itu, guru - guru boleh mendapat tahu mengapa seseorang pelajar tersebut ketagih dan ingin mencuba gejala vape tersebut. Menurut En. Tengku Muhd Khaidir lagi,

"Kalau berbanding dengan kaunseling, maknanya bila kita dah kaunseling, budak itu dah buat. Takkan kita nak kaunseling budak yang taknak buat kan?" 
Mohd Razimi Husin, George Chong, Abdul Rahman Hamid, Baida Azahar, Muaz Muzaffa, Farah Diana Ahmad Kemchi, Nur Ezzaty Mandzoor Ahmed, Zulkarnain Zaharudin, Mohamad Amirul Ismail, Ahmad Naqib Md Norazni @ Md Yasin, Mohamad Alif Azizan.

Masalah Vape di Sekolah Dalam Kalangan Awal Remaja.

Journal of Humanities and Social Sciences, vol. 2, no. 1, pp. 34-46, April 2020. DOI: 10.36079/lamintang.jhass-0201.101

Jikalau seseorang pelajar tersebut telah memulakan sesi kaunseling, sudah tentunya pelajar tersebut telah mengetahui kesalahannya dan akan cuba mengubah tabiatnya dengan berhenti hisap vape. Selain itu, kaunseling tersebut akan lebih berkesan jikalau dilakukan secara peringkat untuk mengetahui keadaan dan progess pelajar tersebut. Menurut En. Tengku Muhd Khaidir.

"kalau berbanding dengan ceramah atau kempen, kita hanya boleh bagitahu secara umum, luas yang mana boleh terima, terima tapi mereka hanya mendengar dan mentafsir benda itu buruk tapi adakah mereka hendak buat atau tidak? Itu terpulang kepada mereka".

Pengkaji mendapati bahawa pendekatan secara kumpulan atau umum kurang berkesan berbanding pendekatan individu. Penerimaan nasihat terhadap kempen vape tersebut akan hanya diterima dan oleh segelintir pelajar dan tidak kepada yang lain. Ini kerana kebanyakkan pelajar hanya mendengar dan mentafsir bahawa vape tersebut buruk.

\subsection{Keberkesanan Sesi Kaunseling Terhadap Pelajar yang Terlibat dalam Gejala Vape}

Peranan perkhidmatan kaunseling individu di sekolah termasuk membantu pihak sekolah menangani masalah disiplin pelajar, membantu peningkatan akademik, kepimpinan, kerjaya dan memulihkan masalah muka, yang berasingan daripada rawatan perubatan. Hasil daripada sesi tersebut sedikit sebanyak dapat mengurangkan kadar penggunaan vape dalam kalangan pelajar sekolah. sahsiah pelajar di sekolah. Tujuannya supaya setiap pelajar seimbang dari segi jasmani, emosi, rohani dan intelek.

Dalam sesi kaunseling individu, guru bimbingan dan kaunseling membantu individu membuat pilihan atau keputusan sendiri untuk mencapai sesuatu matlamat. Kaunseling individu biasanya digunakan untuk membantu pelajar yang ketagihan dan terlibat dalam menghisap vape. Ulasan ini melihat kepada ujian-ujian berkaitan kaunseling oleh kauselor dan guru-guru lain yang terlatih dan sentiasa mengabil berat terhadap pelajar-pelajar dan sentiasa menyediakan satu atau lebih sesi muka ke muka.

Menurut guru yang ditemubual, di sekolah tersebut mempunyai seorang guru yang sangat penyayang seperti ibu kepada anak-anak. Guru tersebut merupakan kauselor di sekolah dan sentiasa memantau pergerakan para pelajar beliau yang mempunyai masalah dan akan membantu pelajar tersebut untuk menyelesaikan masalah tersebut secara sesi kaunseling. Sesi kaunseling akan diberikan kepada pelajar terlibat dalam penggunaan vape secara individu. Sesi tersebut akan sedikit sebanyak membantu dalam menyelesaikan bukan sahaja masalah penggunaan vape malahan pelbagai masalah lain. Penggunaan vape ini selalunya berpunca daripada rakan sebaya, ibu bapa dan budaya luar yang kerap ditontonkan oleh pelajar ini.

Sesi kaunseling ini selalunya akan berjaya menyelesaikan masalah yang berlaku kerana ia dijalankan secara individu. Guru kauselor akan bertanya kepada pelajar yang bermasalah tersebut dengan lemah lembut supaya pelajar berasa selesa dengan sesi pertanyaan dan luahan tersebut.

"Jadi pendekatan yang telah Ustazah Latifah memberikan, dia memberi nasihat secara tidak keras tetapi secara lembut tapi mendalam dan kita dapat melihat efeknya apabila pelajar tersebut dia telah tak buat perkara - perkara negatif dan dalam masa yang sama pihak sekolah berbincang dan membuat sesuatu mesyuarat untuk memantau pergerakan pelajar tersebut”.

Sesi kauseling yang diberikan secara lemah lembut dan tiada kekerasan akan dapat lebih menyenangkan pelajar yang bermasalah penggunaan vape ini. Pelajar tersebut akan rasa diri dihargai dan disayangi oleh guru-guru menyebabkan penggunaan vape dalam kalangan mereka akan berkurangan. Hasil yang dapat daripada sesi kauseling akan memberikan kesan terhadap pelajar tersebut untuk tidak mengulangi perbuatan yang salah tersebut. Selepas sesi kaunseling ini diberikan kepada pelajar akan menyedari tentang bahayanya penggunaan vape ini.

Namun, jika sesi kaunseling ini tidak berkesan, pihak sekolah akan ke langkah yang lebih drastik. Akan tetapi, mestilah mendapat persetujuan daripada ibu bapa. Langkah maksimum yang boleh dijatuhkan ke atas pelajar yang bermasalah ini hanyalah dengan menggantung sekolah hanya selepas surat-surat amaran telah diberikan. 
Mohd Razimi Husin, George Chong, Abdul Rahman Hamid, Baida Azahar, Muaz Muzaffa, Farah Diana Ahmad Kemchi, Nur Ezzaty Mandzoor Ahmed, Zulkarnain Zaharudin, Mohamad Amirul Ismail, Ahmad Naqib Md Norazni @ Md Yasin, Mohamad Alif Azizan.

Masalah Vape di Sekolah Dalam Kalangan Awal Remaja.

Journal of Humanities and Social Sciences, vol. 2, no. 1, pp. 34-46, April 2020. DOI: 10.36079/lamintang.jhass-0201.101

"Tapi kalau dia buat lagi, kita pun telah berbincang dengan ibu bapa dan pihak sekolah boleh menjatuhkan hukuman kepada pelajar tersebut dengan cara memberi surat amaran. Kalau dia masih buat lagi, kita akan menggantungkanlah pelajar tersebut sebagai hukuman yang paling maksimum pada saya di sekolah ini. Tapi setakat ini, kalau pelajar sekolah rendah, kita panggil mak ayah dah jadi, dah mengalah dan dah takut."

Menurut guru tersebut lagi, pelajar berumur 12 tahun yang masih bersekolah rendah ini, dengan cara memanggil ibu bapa ke sekolah sahaja sudah cukup untuk mengatasi masalah ini. Pada peringkat awal remaja, pelajar mudah untuk diurus kerana mereka masih lagi dengar serta patuh pada guru dan ibu bapa. Kesimpulannya, pihak sekolah terutamanya unit kaunseling amatlah cakna tentang permasalahan berkaitan vape ini kerana kita dapat lihat cikgu-cikgu di sekolah tersebut terus mengambil langkah yang sepatutnya dan tidak hanya mengharapkan kaunselor sahaja untuk menyelesaikan perkara ini.

\subsection{Kesan Penggunaan Vape Dalam Kalangan Pelajar Sekolah Rendah}

Berdasarkan kajian di sekolah rendah agama, pelajar yang mengambil atau menghisap vape akan cenderung untuk lebih berkelakuan negatif di sekolah. Penggunaan vape kalangan pelajar tersebut adalah berpunca daripada persekitaran sekolah dan budaya sesetengah pelajar tersebut. Faktor untuk pelajar untuk mengambil atau menghisap vape itu adalah sebagai satu kebanggaan di sekolah. Menurut apa yang saya dapati hasil daripada temubual daripada seorang guru di Sekolah Rendah Agama Al-Mutaqin terdapat tiga kesan penggunaan vape dalam kalangan pelajar sekolah tersebut.

Menurut Cikgu Tengku Mohd Khadir, kesan daripada masalah penggunaan vape oleh pelajar di Sekolah Rendah Agama Al-Mutaqqin adalah mempengaruhi rakan sebaya mereka untuk terpengaruh dalam gejala menghisap vape di dalam sekolah. Menurut Papalia [16] perkembangan sosial pada peringkat remaja banyak melibatkan kelompok rakan sebaya berbanding dengan orang tua. Apabila pelajar itu membawa vape ke sekolah dan menghisapnya, ianya telah menjadi satu kebanggaan yang boleh menyebabkan kawan mereka turut terikut dan menghisapnya. Pelajar yang menghisap vape itu akan mengatakan bahawa vape memberi satu kepuasan apabila menghisapnya. Hal ini menyebabkan rakan sebaya mereka untuk mencuba pengalaman negatif itu. Pada waktu ini, awal remaja sedang mencari identiti sebenar mereka. Mereka lebih gemar meniru perwatakan yang dilihat oleh mereka seharian terutamanya oleh pelajar - pelajar di sekolah.

Selain itu, penggunaan vape dalam kalangan pelajar juga memberi kesan kepada masalah disiplin pelajar itu untuk cenderung melakukan jenayah seperti mencuri di sekolah mahupun di luar kawasan sekolah. Menurut Cikgu Tengku Mohd Khadir, beliau menjelaskan bahawa alasan pelajar yang telah ditangkap atas kesalahan menghisap vape adalah bahawa vape itu bukan kepunyaan pelajar itu. Antara alasan pelajar selepas disoal oleh guru disiplin bahawa vape yang di bawa ke sekolah adalah pelajar itu mengambil vape dari abangnya dan juga pelajar itu terjumpa vape di kawasan masjid. Selain itu juga, cikgu Tengku Arif juga mengatakan apabila pelajar itu mula ketagih untuk menghisap vape, dia tidak mampu untuk membeli bahan bakar seperti perisa vape itu. Perkara ini mendorong pelajar itu untuk melakukan jenayah mencuri di sekolah. sebagai contoh jenayah mencuri yang dilakukan oleh pelajar itu adalah seperti mencuri duit daripada rakan mereka dan juga daripada guru-guru.

Kamus Dewan Edisi Keempat telah mendefinisikan sahsiah sebagai keperibadian atau peribadi di mana peribadi yang utama ialah menuntut ilmu dan melengkapkan proses pembinaan peribadi atau sebagai insan yang terpuji. Kajian temubual telah dilakukan terhadap salah seorang guru di Sekolah Rendah Agama Al-Mutaqqin dilakukan untuk mengkaji perubahan sahsiah mereka apabila terlibat dengan gejala vape.

Menurut guru tersebut, pelajar-pelajar yang menghisap vape telah menghisap sesuatu yang negatif dan serkara ini secara tidak langsung akan merubah sahsiah mereka. Sebagai contoh, pelajar - pelajar bermasalah tersebut akan menjadi samseng iaitu perubahan tingkah laku positif kepada negatif. Mereka merasakan bahawa mereka sudah cukup dewasa sehingga berani untuk melanggar peraturan sekolah dan secara tidak langsung akan menyebabkan mereka menjadi lebih agresif. Guru terbabit turut menambah pelajar yang agrresif itu akan lebih terdorong untuk melanggar peraturan sekolah.

Kesan daripada penggunaan vape dalam kalangan pelajar di sekolah ini juga adalah pelajar bersikap menunjuk-nunjuk tentang sesuatu hal yang negatif. Pendapat yang kedua yang dikatakan oleh Cikgu Tengku Mohd Khadir tentang kesan pelajar menghisap vape di sekolah adalah untuk menunjuk-nunjuk kepada pelajar lain bahawa dia telah melakukan kesalahan di sekolah. Sikap 
Mohd Razimi Husin, George Chong, Abdul Rahman Hamid, Baida Azahar, Muaz Muzaffa, Farah Diana Ahmad Kemchi, Nur Ezzaty Mandzoor Ahmed, Zulkarnain Zaharudin, Mohamad Amirul Ismail, Ahmad Naqib Md Norazni @ Md Yasin, Mohamad Alif Azizan.

Masalah Vape di Sekolah Dalam Kalangan Awal Remaja.

Journal of Humanities and Social Sciences, vol. 2, no. 1, pp. 34-46, April 2020. DOI: 10.36079/lamintang.jhass-0201.101

menunjuk pelajar itu menjadi satu kebanggaan kepada diri sendiri. Sikap itulah yang menyebabkan pelajar itu lebih cenderung untuk melakukan perkara yang negatif di sekolah. Dalam permikiran pelajar tersebut pada masa itu, adalah untuk menarik perhatian pelajar lain bahawa dia lebih hebat dan matang berbanding dengan pelajar yang lain.

\subsection{Tahap Perkembangan Vape Di Sekolah}

Berdasarkan soalan iaitu apakah tahap perkembangan vape di sekolah adakah ia semakin meningkat atau masih berada pada tahap yang masih boleh dikawal? Penggunaan vape dalam kalangan murid sekolah ketika ini membimbangkan.Setiausaha Agung Majlis Kawalan Tembakau Malaysia, Muhammad Sha'ani Abdullah berkata, pemantauan dan tidakan harus dilakukan segera termasuk larangan penjualan kepada kanak-kanak dan pelajar sekolah.

Sha'ani mengulas berikutan trend membimbangkan itu sudah melarat ke peringat murid sekolah rendah. Sebelum ini Yang Dipertua Majlis Pengetua Sekolah Malaysia (MPSM), Datuk Sabuddin Sani mengakui, walaupun gejala itu masih pada skala terkawal, namun tindakan proaktif perlu diambil segera oleh semua pihak terutama ibu bapa untuk menangani isu berkenaan.

Dapatan kajian yang boleh disimpulkan menurut Ustaz Tengku perkembangan vape disekolah adalah semakin meningkat dan ia sukar dikawal. Hal ini demikian kerana wujudnya vape yang sukar untuk dikenal. Ada yang jenis-jenis vape bentuk pen, pendrive dan yang terkini bentuk jam. Bendabenda teknologi yang sebegini semakin meluas dan meningkat. Cuma, ia sukar dikawal kerana teknologi yang terkini disebabkan pengetahuan kita yang terbatas. Oleh itu sebagai seorang cikgu, mereka perlu ambil tahu tentang teknologi vape yang terkini dan sentiasa membuat spotcheck secara rawak dalam setiap minggu atau bulan. Kesimpulannya ia memang sukar dikawal melainkan sesuatu kerajaan tersebut mengharamkan penggunaan vape di Malaysia.

Selain itu juga, pada 1 Jun 2019, kerajaan telah mengambil langkah yang drastik membincangkan tentang masalah ketagihan vape dikalangan pelajar. Buktinya, Kementerian Kesihatan akan bekerjasama dengan Kementerian Pendidikan bagi menyiasat kajian mengenai penggunaan rokok elektronik (vape) dalam kalangan pelajar yang dikatakan pada tahap kritikal serta membimbangkan.

Selain itu, menurut Dr Lee Boon Chye, tindakan boleh dikenakan ke atas penjual selain memantau penjualan rokok elektronik itu secara tidak sah dalam talian. Seterusnya, menurut Pegawai Penyelidikan persatuan berkenaan, NV Subbarow, mereka mendapati terdapat segelintir pelajar sekolah berusia seawal 14 tahun sanggup berbelanja melebihi RM60 sebulan bagi meneruskan ketagihan terhadap rokok elektronik itu.

\section{Perbincangan}

Perbincangan dalam kajian ini adalah selaras dengan soalan dan sorotan kajian iaitu "masalah penggunaan vape dalam kalangan pelajar sekolah rendah agama". Berikut adalah merupakan perbincangan dapatan analisis masalah vape. Perbincangan dapatan kajian dibentangkan pada Jadual 4.

Dapatan kajian berdasarkan temubual yang dijalankan ke atas guru sekolah rendah agama analisis usia awal remaja adalah bermula pada puratanya 11 tahun. Dimana dalam purata umur awal remaja merupakan usia perkembangan yang pantas individu dari segi fizikal dan mental. Analisis umur awal remaja dapat dikukuhkan oleh pandangan Azizi et al. [2] remaja dikatakan berusia di antara 11 hingga 21 tahun, merupakan transisi antara zaman kanak-kanak dengan zaman dewasa yang melibatkan perubahan biologi, psikologi, social, dan ekonomi serta melibatkan perubahan peringkat tidak matang ke peringkat matang. Oleh itu, dapatan ini menjelaskan perkembangan di awal remaja sama ada perkembangan positif atau perkembangan yang negatif.

Pada umumnya, vape merupakan rokok eletronik yang digunakan oleh perokok untuk berhenti merokok. Walaubagaimanapun, pengambilan vape ini telah disalah ambil oleh para pelajar sebagai 'trend' kerana terpengaruh dengan persekitaran, media sosial dan sebagainya. Kajian-kajian lepas menunjukan bahawa rokok elektronik atau vape telah adalah produk tembakau yang paling popular dalam kalangan pelajar menengah pertengahan dan menengah atasan di Amerika Syarikat. Perkara ini turut dapat dilihat sendiri penggunaan vape di seluruh negara turut melibatkan para pelajar sekolah. Daripada analisis kajian, pengkaji yang menjelaskan punca awal remaja itu mengambil vape adalah untuk kepuasan diri sendiri sahaja. Mereka tidak memikir kesan kepada mereka terutamanya kesihatan dan perkembangan mereka dalam pembelajaran di sekolah. 
Mohd Razimi Husin, George Chong, Abdul Rahman Hamid, Baida Azahar, Muaz Muzaffa, Farah Diana Ahmad Kemchi, Nur Ezzaty Mandzoor Ahmed, Zulkarnain Zaharudin, Mohamad Amirul Ismail, Ahmad Naqib Md Norazni @ Md Yasin, Mohamad Alif Azizan.

Jadual 4. Perbincangan Dapatan Kajian

\begin{tabular}{|c|c|}
\hline Sorotan Kajian & Hasil Kajian \\
\hline $\begin{array}{l}\text { Kajian terhadap tingkah laku awal remaja } \\
\text { iaitu purata umur } 11 \text { tahun }\end{array}$ & $\begin{array}{l}\text { Awal remaja merupakan transisi antara } \\
\text { zaman kanak-kanak dengan zaman dewasa. } \\
\text { Awal remaja banyak mengalami perubahan } \\
\text { mental dan fizikal. }\end{array}$ \\
\hline $\begin{array}{l}\text { Kajian terhadap permasalahan penggunaan } \\
\text { vape yang membawa kepada punca dan } \\
\text { kesan kepada pengguna terutama pelajar }\end{array}$ & $\begin{array}{l}\text { Hasil kajian yang menjelaskan punca } \\
\text { pelajar itu mengambil vape dan kesan yang } \\
\text { berlaku kepada pelajar. }\end{array}$ \\
\hline $\begin{array}{l}\text { Kajian penggunaan rokok elektronik iaitu } \\
\text { vape dalam kalangan masyarakat sama ada } \\
\text { berleluasan atau tidak dan langkah-langkah } \\
\text { yang dilakukan untuk mengatasi masalah } \\
\text { vape yang berlaku }\end{array}$ & $\begin{array}{l}\text { Hasil kajian dibuktikan melalui kajian yang } \\
\text { dilakukan di sekolah rendah agama dimana } \\
\text { penggunaan vape adalah pada awal remaja. } \\
\text { Kajian juga mendapat langkah telah } \\
\text { dilakukan untuk membasmi masalah } \\
\text { pengambilan vape dalam awal remaja } \\
\text { tersebut }\end{array}$ \\
\hline
\end{tabular}

Seterusnya, dalam konteks analisis pengguna rokok elektronik di Malaysia ialah sebanyak $62 \%$. Perkara ini dapat dibuktikan melalui hasil kajian pengkaji terhadap pelajar Sekolah Rendah Agama Al-Mutaqqin. Peningkatan penggunaan rokok elektronik dalam kalangan pelajar sekolah telah menjadi satu kebimbangan kepada semua pihak akan pelapis negara kita. Langkah-langkah yang telah dilaksanakan oleh pihak yang bertanggungjawab tidak menunujukkan sebarang penurunan statistik penggunaan vape. Sehubungan dengan itu, usaha-usaha yang lebih keras perlulah dikerahkan kepada semua pihak dalam membantu permasalahan ini agar tidak menjadi lebih parah.

\section{Kesimpulan}

Fenomena penggunaan vape menjadi ikutan anak muda dan kanak-kanak. Hal ini amat membimbangkan kerana ia bertentangan dengan Pelan Strategik Kebangsaan Bagi Kawalan Tembakau 2015-2020 dengan misi menjadikan Malaysia negara bebas daripada sebarang bentuk amalan merokok menjelang 2045. Tabiat menghisap vape dalam kalangan kanak-kanak, terutamanya murid sekolah adalah gejala yang menggusarkan guru dan ibu bapa. Tambahan pula, cecair vape yang mengandungi nikotin bukan sahaja boleh menyebabkan ketagihan, malah boleh membahayakan kesihatan kanak-kanak apabila dos berlebihan diambil. Pelbagai perisa dan pewarna dalam cecair vape akan menarik kanak-kanak untuk mencuba. bapa dinasihati memantau anak-anak kerana peranti vape ini boleh datang dalam pelbagai bentuk dan saiz.

Majlis Fatwa Kebangsaan telah mengeluarkan kenyataan mengharamkan penggunaan rokok elektronik atau vape [17]. Pengharaman rokok elektronik atau vape dilihat dari tiga sudut iaitu pertama membahayakan, kedua ia membazir dan ketiga ia memudaratkan kesihatan. Keputusan pengharaman rokok elektronik atau vape oleh Majlis Fatwa Kebangsaan adalah selari dengan pendapat di beberapa negara Islam lain termasuk Bahrain, Kuwait, Qatar dan Emiriah Arab Bersatu [18]. Malah keputusan pengharaman penggunaan rokok elektronik dan vape juga telah dikeluarkan oleh pihak berkuasa di beberapa negeri lain. Namun, sehingga ke hari ini kerajaan masih tidak mengharamkan penggunaan dan penjualan vape dalam kalangan masyarakat Islam di Malaysia. Kerajaan Malaysia tidak mengharamkan penggunaan vape tetapi akan mewujudkan satu undangundang khusus bagi pengawalan rokok elektronik, shisha dan tembakau. Kementerian Kesihatan Malaysia (KKM) yang diketuai Timbalan Menterinya, Dr Lee Boon Chye turut mengambil inisiatif dengan menubuhkan satu Jawatankuasa Khas pada 27 Jun lalu bagi mengawal penggunaan rokok elektronik dan vape, yang juga memberi fokus kepada usaha menangani penjualan alat tersebut kepada pelajar sekolah. Dr Lee berkata jawatankuasa itu akan menjalankan tugasnya secepat mungkin dan merangka rang undang-undang baharu bagi mengawal penggunaan rokok elektronik dan vape yang dijangka dibentangkan akhir tahun ini atau tahun hadapan. 
Mohd Razimi Husin, George Chong, Abdul Rahman Hamid, Baida Azahar, Muaz Muzaffa, Farah Diana Ahmad Kemchi, Nur Ezzaty Mandzoor Ahmed, Zulkarnain Zaharudin, Mohamad Amirul Ismail, Ahmad Naqib Md Norazni @ Md Yasin, Mohamad Alif Azizan.

\section{Rujukan}

[1] C. Rogers, A Theory of Personality and Behavior. London:Coustble, 1951.

[2] Y. Azizi, S. L. Jaafar, H. Shahrin, and B. Yusof, Psikologi Sosial Alam Remaja. Bentong: PTS Publication \& Distributors, 2005.

[3] C. B. Bullen, C. Howe, and M. Laugesen, "Electronic Cigarettes for Smoking Cessation: a Randomised Controlled Trial," Lancet, vol. 382, pp. 1629-1637, 2013.

[4] A. W. K Delaimy, M. G. Myers, E. C. Leas, et al, "E-Cigarette Use in the Past and Quitting Behavior in The Future: a Population-Based Study," American Journal of Public Health, vol. 105, no. 6, pp. 1213-1219, 2015.

[5] A. Yusdirman, "Rokok Elektonik (Vape) - Bahaya atau Membantu Perokok," Majalah Sains, Ogos 21, 2015.

[6] S. Rimer, "Behind the Vapor," BU Today. October 20, 2014. [Online]. Available: http://www.bu.edu/research/articles/ behindthevapor/. [Accessed: November 15, 2019].

[7] N. Saidi, "Vape Bukan Penyelesaian Terbaik Kawal Ketagihan Rokok," Utusan Online. September 1, 2015.

[8] J. F. Etter, and C. Bullen, "A Longitudinal Study of Electronic Cigarette Users," Addictive Behaviour, vol. 39, pp. 491- 494, 2014.

[9] A. Bahtiar and R. Edy, "Pengaruh Brand Equity, Harga, dan Distribusi terhadap Keputusan Pembelian Vape," Diponegoro Journal of Managment, vol. 6, no. 4, pp. 1-10, 2017.

[10] F. Tjiptono, Manajemen Jasa. Yogyakarta: Andi, 2005.

[11] D. Komalasari, and F. H. Avin, "Faktor-Faktor Penyebab Perilaku Merokok pada Remaja," Jurnal Psikologi, vol. 2, no. 1, pp. 1-10, 2000.

[12] S. Gravely, G. T. Fong, and K. M. Cummings, "Awareness, Trial, and Current Use of Electronic Cigarettes in 10 Countries: Findings from the ITC Project," International Journal of Environmental Research Public Health, vol. 11, no. 11, pp. 11691-11704, 2014.

[13] A. S. Hornby, Oxford Advance Learner's Dictionary of Current English 3th Edition. British: Oxford University Press, 1985.

[14] H. A. Asmak, Salah Laku Remaja Masa Kini: Cabaran dan Penyelesaiannya. Kuala Lumpur: UITM Shah Alam, 2016.

[15] H. L Barnes, and D. H. Olson, "Parent-Adolescent Communication and the Circumplex Model," Children Development, vol. 56, pp. 438-447, 1985.

[16] Papalia. Human Development (8th Ed.). Boston: McGraw-Hill, 2001.

[17] Anonymous, "Kronologi Isu Vape di Malaysia," Sinar Harian Online, Disember 31, 2015. [Online]. Available: http://www.sinarharian.com.my/nasional/2015-kronologi-isu-vape-dimalaysia 1.467 532. [Accessed: May 25, 2016].

[18] Anonymous, "Majlis Fatwa Kebangsaan Putuskan Vape Haram," Sinar Harian Online. Disember 22, 2015. [Online]. Available: http://www.sinarharian.com.my/nasional/majlis-fatwakebangsaan-putus kan - vape-haram-1.464426. [Accessed: May 25, 2016]. 